PERM JOURNAL OF PETROLEUM AND MINING ENGINEERING ВЕСТНИК ПНИПУ. ГЕОЛОГИЯ. НЕФТЕТАЗОВОЕ И ГОРНОЕ ДЕЛО ISSN 2224-9923 Volume/Tom 19 №3 2019

http://vestnik pstu.ru/geo/

UDC 622.276:552.578.2.061.4

Article / Статья

(c) PNRPU / ПНИПУ, 2019

\title{
ANALYSIS OF THE FRACTAL STRUCTURE AND STOCHASTIC DISTRIBUTION OF PORES IN OIL AND GAS RESERVOIRS
}

Adalat B. Hasanov, Gizgait G. Abbasova

Azerbaijan State Oil and Industry University, Baku, Azerbaijan (20 Azadlyg av., Baku, AZ1010, Republic of Azerbaijan)

\section{ОЦЕНКА ФРАКТАЛЬНОЙ СТРУКТУРЫ И СТОХАСТИЧЕСКОГО РАСПРЕДЕЛЕНИЯ ПОРОВЫХ ПУСТОТ НЕФТЕНОСНЫХ КОЛЛЕКТОРОВ}

\section{А.Б. Гасанов, Г.Г. Аббасова}

Азербайджанский государственный университет нефти и промышленности (AZ1010, Азербайджан, г. Баку, пр. Азадлыг, 20)

Received / Получена: 22.02.2019. Accepted / Принята: 01.08.2019. Published / Опубликована: 27.09.2019

Key words:

interparticle porosity, terrigenous reservoirs, particle packing, fractality index, fluid filtration, particle size distribution analysis, prevailing particle sizes, permeability and porosity properties.
Ключевые слова: межзерновая пористость, терригенные коллекторы, упаковка зерен, показатель фрактальности, фильтрация флюидов, гранулометрический анализ, доминирующие фракции, фильтрационноемкостные свойства.
It is known that the natural potential of terrigenous reservoirs' capacity significantly depends on interparticle porosity and particle packing type. Other significant factors that impact reservoir porosity are the shape of particles and the proportion of content and distribution of particles of various sizes in the rock. The attempts to simulate a net effect of factors influencing the multimodal distribution of interparticle porosity are well known; some of them are discussed in this work. The simulated data will be compared with actual measured data, obtained from particle size distribution analysis of core samples from a well-known and long operated oil and gas field in Azerbaijan. For the purpose of the survey, these measured data were generalised and analysed in detail.

The research covers the most typical for the region particle size fractions: pelite, silt, fine-grained sand, and mediumgrained sand. Pie charts of the particle size distribution analysis results indicate that in the first group of rocks (argillaceous silt sand) the largest portion is represented by $0.175 \mathrm{~mm}$ particle size fraction. Two other particle size fractions of 0.055 and $0.01 \mathrm{~mm}$ constitute approximately the same potions, and, finally, the coarse-grained fraction $(0.25 \mathrm{~mm})$ represents an insignificant part of the total rock volume and may be neglected.

Though the apparent correlation between porosity quality and such factors as particle size distribution and mechanical densification of sediments were identified, still the calculated paired correlation coefficient between particle size fractions and parameters, used to average particle size distribution and sort rocks by their type have shown that these are two independent and unrelated functional dependencies. At the same time, the influence of particular fractions and, which is more important, the influence of their proportions on the interparticle porosity is not the same. A more detailed simulation of multimodal distribution has shown that in this case, the use of fractal concepts proved to be more efficient. As an alternative, we have analysed a method for the evaluation of rock oil-bearing properties based on calculated dependence between the fractality index and oil saturation.

Известно, что природный потенциал продуктивной вместимости терригенных коллекторов в значительной степени определяется их межзерновой пористостью и характером упаковки зерен. Однако, помимо этого, на пористость коллекторов большое влияние оказывают форма зерен, а также соотношение содержания и распределения зерен различных размеров в объеме породы. Широко известны попытки моделирования результирующего эффекта влияющих факторов на мультимодальное распределение межзерновой пористости, некоторые из которых рассматриваются в данной работе. Вместе с тем для сравнения с реальными данными здесь также описаны детальные аналитические обобщения фактических результатов гранулометрического анализа керна из скважин одного из известных и длительно эксплуатируемых нефтегазовых месторождений Азербайджана.

Исследованиями были охвачены наиболее характерные для региона пелитовая, алевритовая, мелкозернистая песчаная и среднезернистая песчаная фракции. Результаты исследований по распределению фракций представлены в виде круговых диаграмм, анализ которых показывает, что в составе первой группы пород (глинисто-алевритовых песках) доминирует фракция с размером зерен 0,175 мм. Две другие фракщии с размером зерен 0,055 и 0,01 мм занимают примерно одинаковый объем, наконец, фракция грубых зерен ( 0,25 мм) составляет незначительную часть объема и может не учитываться.

Установленные закономерности изменения пористости в зависимости от фракционного состава и механического уплотнения осадков весьма показательны, однако вычисление парного коэффициента корреляции между фракциями и параметрами, усредняющими гранулометрический состав и отражающими сортированность пород, показало, что они являются самостоятельными, не связанными между собой функциональными зависимостями. При этом влияние отдельных фракций, а главное - их соотношения на величину межзерновой пористости неодинаково. Детализация процесса моделирования мультимодального распределения позволила установить, что в данном вопросе более эффективно применение фрактальных концепций. Как вариант рассмотрен способ оценки коллекторских свойств нефтесодержащих пород на основе расчетной зависимости между показателем фрактальности и нефтенасыщенностью.

\footnotetext{
Adalat B. Hasanov (Author ID in Scopus: 5379-7905) - Doctor of Physics and Mathematics, Head of Laboratory of Physical Properties of Mineral Deposits Rocks (tel.: +994 5022312 55, e-mail: adalathasanov@yahoo.com). The contact person for correspondence.

Gizgait G. Abbasova - Lead Engineer (tel.: +994 5089903 70, e-mail: qizqayit_abbasova@yahoo.com)
}

Гасанов Адалят Бадал оглы (Author ID in Scopus: 5379-7905) - доктор физико-математических наук, заведующий лабораторией физических свойств горных пород месторождений полезных ископаемых (тел.: +994 5022312 55, e-mail: adalathasanov@yahoo.com). Контактное лицо для переписки.

Аббасова Гызгаит Гудрет кызы - ведущий инженер (тел.: +994 5089903 70, e-mail: qizqayit_abbasova@yahoo.com). 


\section{Introduction}

On the one hand, the efficiency of oil and gas filed development process and hydrocarbon extraction of productive strata significantly depends on the initial permeability and porosity properties of reservoir rocks. On the other hand, in the process of development and large-scale intrastratal filtration of fluids, different types of deformation processes occur in a stratum: from elastic deformation to plastic fracture [1-5]. These processes, in their turn, cause secondary changes in permeability and porosity properties of reservoir rocks [6-9].

For instance, plastic fracture of a stratum may cause a change in the pore volume by the increase in the specific surface area of particles, which leads to the reduction of the reservoir pressure $[10,11]$, as it is known that

$$
P=\frac{F}{S}
$$

where $F$ is the load (reservoir pressure); $S$ is the pore surface area (the surface area of rock-forming particles).

This results in conditions conducive to abnormally low reservoir pressure. This particular case is based on the assumption that oil and gas-bearing rocks are porous or fractured rock media characterized by a random distribution of rock-forming particles, shape and size of capillaries and cracks $[10,12]$. In such rock environments, effective reservoir pressure is one of the main factors of intrastratal migration and smooth extraction of hydrocarbons [11]. This is a counter-pressure of fluid accumulated in rock pores to the rock pressure exerted by the weight of the overlying strata. The value of the effective reservoir pressure is calculated as follows:

$$
P_{\text {eff }}=P_{\text {rock }}-P_{\text {pore }},
$$

where $P_{\text {rock }}$ is the rock pressure; $P_{\text {pore }}$ is the reservoir pressure.

When pores are saturated with gases, the response of fluid can be neglected, otherwise liquid fluids (water and oil) are the main factors determining the reservoir pressure counteracting the rock pressure.

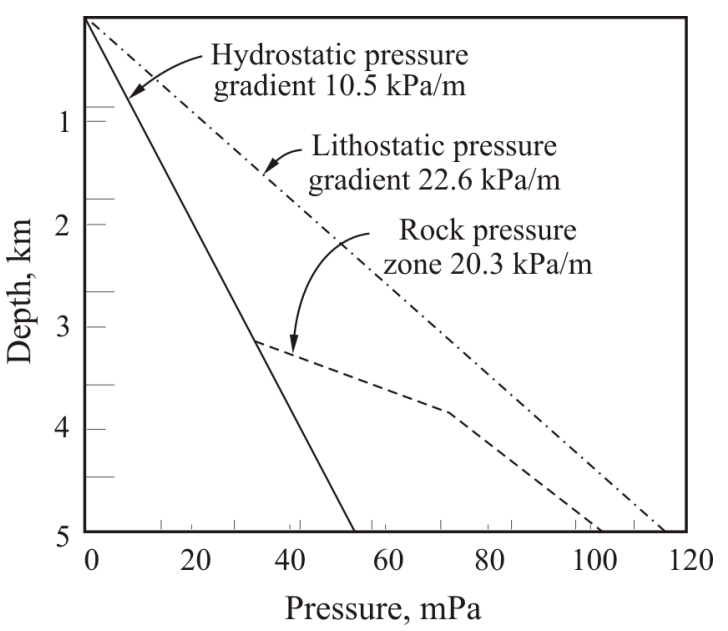

Fig. 1. Measured downwards average gradient and high pressure area [21]

Porosity, $\%$

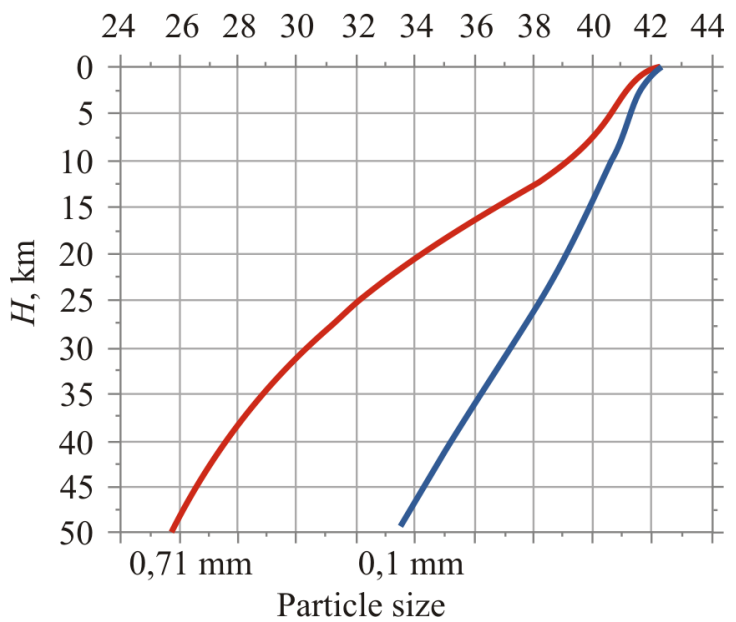

Fig. 2. Downwards mechanical densification of well-sorted sand [10]

\section{Statement of the problem}

Multiple theoretic calculations and in situ measurements in deep wells [13-20] allow us to obtain values of subterranean lithostatic and hydrostatic pressures which can be represented numerically by gradients of lithostatic and hydrostatic pressures. For instance, the lithostatic pressure gradient is determined based on the sedimentation rate, which contributes to the degree of densification and bulk density of rock particles. The hydrostatic gradient is calculated based on the density and height of a liquid column. In Figure 1, provides an example of downwards lithostatic and hydrostatic gradient measurement; it shows that the hydrostatic pressure gradient is $10.5 \mathrm{kPa} / \mathrm{m}$, and the lithostatic gradient is $22.6 \mathrm{kPa} / \mathrm{m}$, i.e. approximately two times higher. 


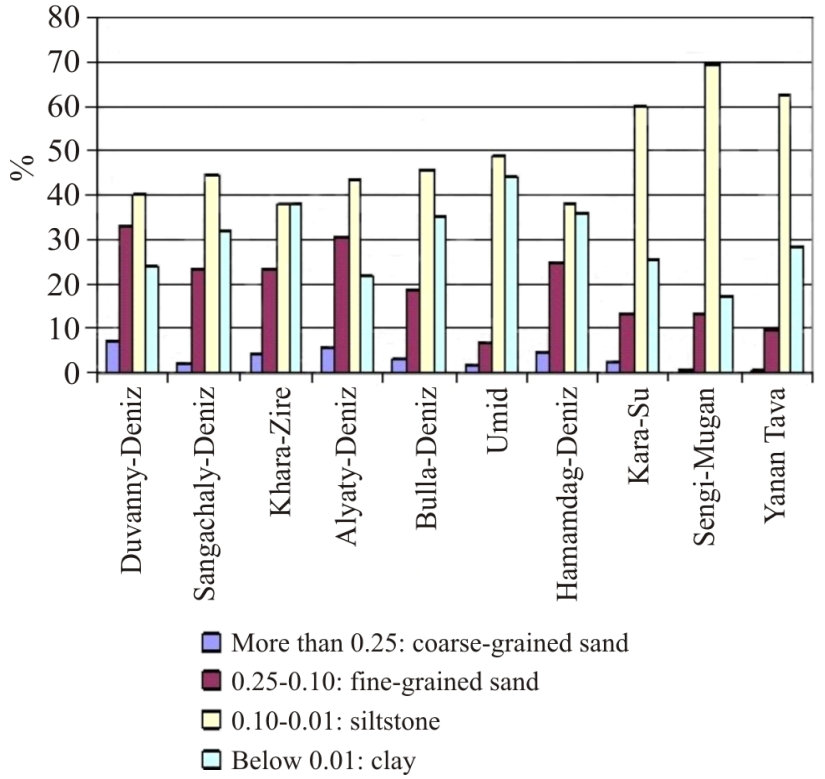

Fig. 3. Various particle size distributions in terrigenous reservoirs in some oil and gas fields of Azerbaijan

Under stable conditions, contacts between separate particles cause adhesion increased by gravity. However, in the process of densification, the contact forces between particles are neutralized, the friction between particles tends to zero, and quicksands develop (the liquefaction of sands) [10, 22-28]. In short, the process of sediments mechanical densification can be described through the example of well-sorted sand (Figure 2): at the initial stage of sedimentation (at a depth of $0-2 \mathrm{~km}$ ), well-sorted sand, being free, still can be significantly compressed. For instance, test densification of loose sand having its initial porosity of $40-42 \%$ shows that at $20-30 \mathrm{MPa}$ load porosity can decrease down to 35-25\% depending on the strength and size of particles, which corresponds to the conditions experienced by rocks under normal rock pressure at the depth of $2-3 \mathrm{~km}$. In these conditions, well-sorted coarse sand is more compressible than fine-grained sand [29-31]. Therefore, the increased pressure reduces the effective pressure but maintains porosity due to the reduction of mechanical densification. At the same time, the porosity change under mechanical densification can differ significantly depending on the textural and mineralogical composition, which widely uses data of the particle size distribution analysis.

In addition to the above, fine-grained environments (having pore sizes up to $0.1 \mathrm{~nm}$ ) can be described as systems having a fractal structure characteristic of random distributions of pores, capillaries, and fracture channels [29, 32-35]. The use of fractal principles for the development of hydrocarbon fields facilitates the analysis of the turbulent flow of fluid and gas within reservoir pores.

\section{Main Points}

The studies of the pore volume densification patterns in productive reservoirs and the correlation between the specific surface area and oil saturation described in this work used analysis of generalised data from a well-known and long operated oil and gas field in Azerbaijan [36] (Table 1). However, as we know, the specific surface area of pore volume in terrigenous sediments is determined by particle size distribution in the rock matrix. Therefore, before calculating the specific surface area, we analysed data on particle size distribution in the core material and determined the degree of the influence of particular fractions (including prevailing particle size fractions) on the porosity of different reservoirs. Thus the analysed core samples were divided into four groups depending on the rock type: argillaceous-silty sand, argillo-arenaceous siltstone, sandy-argillaceous siltstone, and argillaceous sandy loam.

The following four groups were formed based on the particle (grain) size: pelite $(0.01 \mathrm{~mm}$ and less), silt $(0.055 \mathrm{~mm})$, fine-grained sand $(0.175 \mathrm{~mm})$ and medium-grained sand $(0.25 \mathrm{~mm})$. The selected grading of particle sizes of rock-forming particles is commonly accepted in the fields of the region [25-26, 39] and is shown in Figure 3.

The results of our analyses of the particle size distribution of the studied groups are given in Figure 4 as pie charts; the figure shows that in the first group of rocks (argillaceous-silty sand) the fraction having particle size of $0.175 \mathrm{~mm}$ prevails. Other two fractions having a particle size of 0.055 and $0.01 \mathrm{~mm}$ - represent almost similar portions, and, finally, the coarse-grained fraction $(0.25 \mathrm{~mm})$ is represented by an insignificant portion and may be neglected.

Table 2 describes the correlation between the porosity of the studied rocks and prevailing and secondary particle sizes.

This data shows that an increase in the prevailing fraction $(0.175 \mathrm{~mm})$ content in the first group of rocks (argillaceous-silty sand) leads to porosity increase, whereas an increase in the content of the fraction having a particle size of $0.055 \mathrm{~mm}$ reduces the porosity of this group of rocks. In the remaining three groups of rocks, the fraction having a particle size of $0.055 \mathrm{~mm}$ prevails, and the percentage of 
fractions having a particle size of 0.175 and $0.01 \mathrm{~mm}$ is different. Here, in the same way, as in the first group of rocks, the coarse-grained fraction $(0.25 \mathrm{~mm})$ is represented by an insignificant portion and may be neglected.

As for the argillo-arenaceous siltstone group of rocks, we revealed the influence of the prevailing fraction $(0.055 \mathrm{~mm})$ and fraction having a particle size of $0.175 \mathrm{~mm}$ (see Table 2) on porosity.

These data demonstrate that an increase in the content of the prevailing fraction and fraction having a particle size of $0.175 \mathrm{~mm}$ in argillo-arenaceous siltstone leads to increased porosity.
As opposed to the argillo-arenaceous siltstone group, the prevailing fraction $(0,055 \mathrm{~mm})$ and a coarser fraction $(0,25 \mathrm{~mm})$ have a negative effect on the porosity of sandy-argillaceous siltstone.

And finally, for the last group - the argillaceous sandy loam group - the influence of the prevailing $(0.055 \mathrm{~mm}$, fine $)$ and secondary $(0.175 \mathrm{~mm}$, coarser $)$ fractions is contrary (the same way as in the argillaceous-silty sand group). In particular, an increase in the fine $(0.055 \mathrm{~mm}$, prevailing $)$ fraction content in argillaceous sandy loam leads to porosity reduction, whereas an increase in the coarser fraction $(0.175 \mathrm{~mm})$ content increases the porosity of argillaceous sandy loam (see Table 2).

Table 1

Average values of particle size distribution, porosity, specific pores surface area, and oil and gas bearing capacity of the studied rock types

\begin{tabular}{|c|c|c|c|c|c|c|c|}
\hline \multirow{2}{*}{$\begin{array}{c}\text { Rock type } \\
\text { (number of samples) }\end{array}$} & \multicolumn{4}{|c|}{ Particle size fraction, $\mathrm{mm} \%$} & \multirow{2}{*}{ Porosity } & \multirow{2}{*}{$\begin{array}{c}\text { Specific } \\
\text { surface area }\end{array}$} & \multirow{2}{*}{ Oil content } \\
\hline & 0.25 & 0.175 & 0.055 & 0.01 & & & \\
\hline Argillaceous-silty sand (14) & 2.44 & 54.13 & 28.01 & 15.31 & 25.62 & 1266 & 15.2 \\
\hline Argillo-arenaceous siltstone (6) & 0.39 & 27.49 & 55.54 & 16.58 & 25.04 & 1725 & 16.74 \\
\hline Sandy-argillaceous siltstone (3) & 0.37 & 12.43 & 60.41 & 26.90 & 23.07 & 1851 & 15.18 \\
\hline Argillaceous sandy loam (5) & 0.68 & 39.38 & 43.91 & 16.59 & 24.56 & 1611 & 17.53 \\
\hline
\end{tabular}

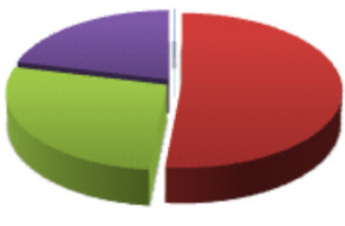

0,25

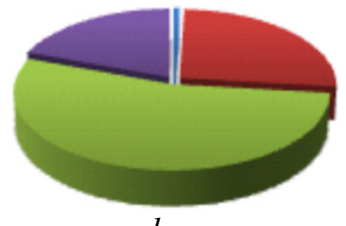

$b$

घ 0,175

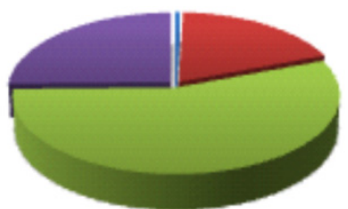

$c$

घ 0,055

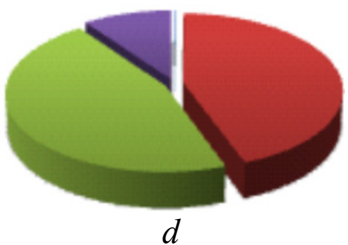

0,01

Fig. 4. Particle size distribution by groups of rocks: $a$ - argillaceous-silty sand;

$b$ - argillo-arenaceous siltstone; $c$ - sandy-argillaceous siltstone; $d$ - argillaceous sandy loam

Table 2

The influence of particle size distribution on the porosity of different types of rocks

\begin{tabular}{|l|c|c|}
\hline \multirow{2}{*}{ Group of rocks } & Particle size, mm & $\begin{array}{c}\text { Dependence of porosity and particle size } \\
\text { distribution }\end{array}$ \\
\hline \multirow{2}{*}{ Argillaceous-silty sand } & 0.175 & $Y=0.3312 X+7.14$ \\
\hline \multirow{2}{*}{ Argillo-arenaceous siltstone } & 0.055 & $Y=-0.1376 X+29.196$ \\
\cline { 2 - 3 } & 0.055 & $Y=0.6338 X+37.926$ \\
\cline { 2 - 3 } Sandy-argillaceous siltstone & 0.175 & $Y=0.4875 X+10.75$ \\
\hline \multirow{2}{*}{ Argillaceous sandy loam } & 0.055 & $Y=-1.9775 X+106.04$ \\
\cline { 2 - 3 } & 0.25 & $Y=0.3312 X+7.14$ \\
\cline { 2 - 3 } & 0.055 & $Y=0.3312 X+7.14$ \\
\hline
\end{tabular}


Though the revealed dependence of porosity patterns changes on the particle size distribution and mechanical densification of sediments is quite obvious, still, as we have mentioned above, porosity may vary significantly depending on the textural and mineralogical composition of rocks. This is well demonstrated by the researches [10] where the dependence of porosity on mechanical densification was defined using also the parameters averaging particle size distribution in rocks $\left(M_{d}-\right.$ coarseness), and the coefficients showing sediment sorting $\left(K_{\text {sort }}\right.$, $H r$, and $M_{f}$ - the maximum content of any particle size fraction). The paired correlation analysis of the fractions and the parameters averaging particle size distribution and reflecting sorting of rocks is shown in Table 3. This data show that the averaged particle size (on the one hand) and sorting of rocks (on the other hand) are independent and unrelated functional dependencies. At the same time, there is a close correlation between some parameters (for instance, rock coarseness and $M_{d}$ ).

Particle size. It is well known that the influence of particle size on interparticle porosity of rocks with random packing of spherical particles depends on the stability of active internal frictional forces and adhesion between separate particles [1]. These forces are proportional to the specific surface area of particles which is taken as equal to the total surface area of particles per unit of solid volume and are inversely proportional to particle size. Such dependency means that with all other factors being equal, in case of lower porosity the contribution of coarse particles is much less than the contribution of fine particles [37-44]. This general rule is shown in Figure 3, which demonstrates that an increase in the porosity of the sedimentary rock, having particles of a particular size, becomes significant only when particles size is lower than $0.1 \mathrm{~mm}$ (100 microns). In case of coarser sizes (over $100 \mathrm{~mm}$ ), frictional forces decrease and porosity goes down to a state of random packing without frictional forces, which occurs when porosity is 0.399 , and in this state, porosity does not depend on particle size any more.

Further porosity decrease is not possible for randomly packed spherical particles, except for the cases when particles are subject to irreversible deformation as a result of dissolution, recrystallization, destruction, plastic flow, etc. Such porosity decrease is called particle packing compaction.

Particle packing. In theoretical geometry, there are several patterns of standard particle packing in rocks exhibiting maximum possible interparticle porosity values (Table 4, Figure 5 ). It has also been revealed [21, 39-44], that the theoretical maximum porosity $(0.476)$ of sedimentary rock having cubic packing of spherical particles of the same size does not depend on particle size.

Table 3

Paired coefficients of correlation between particle size fractions and parameters averaging particle size distribution and reflecting sorting of rocks

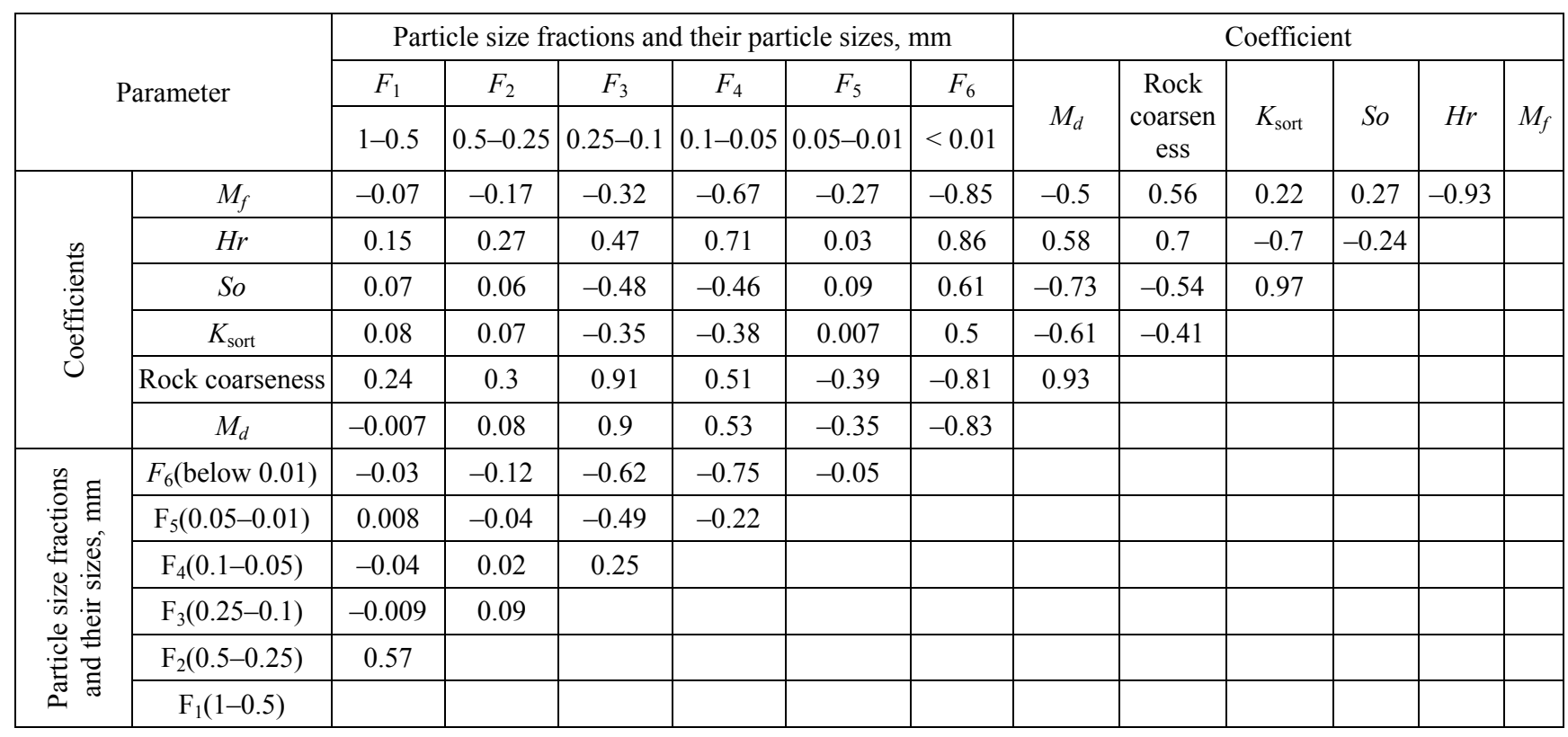


Shape of particles and distribution of particles of different sizes in the rock. Table 5 presents information on the dependency between various shapes of particles and interparticle porosity; Figure 6 compares rounded and angular particles and proves that porosity is higher when more angular particles are present in rock than in case of sub-spherical particles rock composition [21, 39-44].

Table 4

Maximum porosity for different packing patterns

\begin{tabular}{|l|c|}
\hline \multicolumn{1}{|c|}{ Packing } & Maximum porosity \\
\hline Random & $\begin{array}{c}0.399 \text { and more } \\
\text { (particle size-dependent) }\end{array}$ \\
\hline Cubical & 0.476 \\
\hline Rhombic & 0.395 \\
\hline Rhombohedral & 0.260 \\
\hline Tetragonal & 0.302 \\
\hline
\end{tabular}

Table 5

Dependence of particle shape and interparticle porosity

\begin{tabular}{|l|c|}
\hline \multicolumn{1}{|c|}{ Particle shape } & $\begin{array}{c}\text { Interparticle porosity } \\
\text { (max) }\end{array}$ \\
\hline Spherical & 0.399 \\
\hline Cubical & 0.425 \\
\hline Cylindrical & 0.429 \\
\hline Disk-shaped & 0.453 \\
\hline
\end{tabular}

It has already been mentioned above that apart from particles shape the proportions of particle size fractions (particles of various sizes) content in the rock volume and their distribution influence the reservoir porosity very much, and the influence of particular fractions and (which is more important) the influence of their proportion on interparticle porosity differs. It is rather difficult to simulate the actual distribution of particle sizes in a rock, which is often multimodal in nature; therefore, to better understand the net effect, the boundary conditions of calculations are simplified down to a variable mixture of particles of two sizes in a limited amount of the rock volume [21].

A schematic description of the simulation process is provided in Figure 7, where a rock model consists of particles of two sizes, one of which is $1 / 100$ of the diameter of the other. There are two possibilities here:

- in the first case, the rock has a sufficient amount of coarse particles representing the general rock matrix, and the added smaller particles reduce the rock porosity because finer particles fill spaces between coarser particles (see Figure 7, $a$ );

- in the second case, the general the rock matrix consists of finer particles. Here the pores are between fine particles (see Figure 7,b).

It is clear that if some amount of fine particles is removed and replaced with solid coarse particles, porosity will decrease, as in this case a portion of small particles contributing to certain porosity is replaced with continuous massive material having no internal porosity. In Figure 7 continuous lines $G R$ and $R F$ or $R M$ represent theoretical curves for both cases. It is interesting to note that as the difference in particle size grows from $6: 3$ to $50: 5$, the actual porosity approaches theoretical values. It has been also noted that the minimum porosity is not impacted by the correlation of particle diameters. This minimum porosity corresponds approximately to $20-30 \%$ of the diameter of smaller particles. It should also be noted that porosity of a mixture of two sizes is always lower than in any pure phase [21].
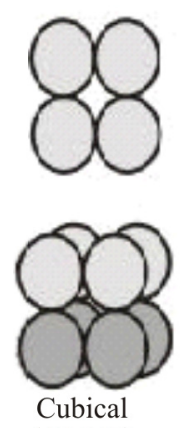

$(47.6 \%)$
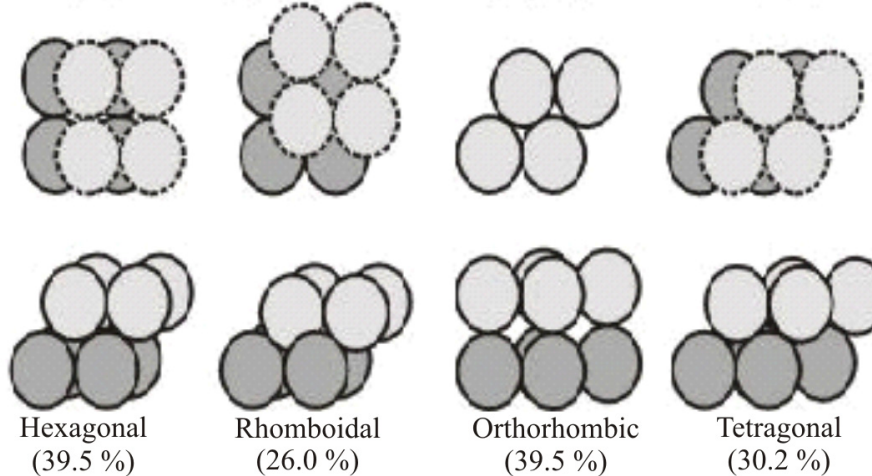

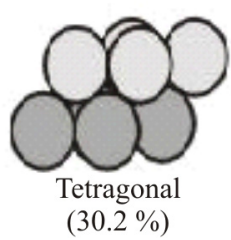

Fig. 5. Interparticle porosity for standard packing patterns 


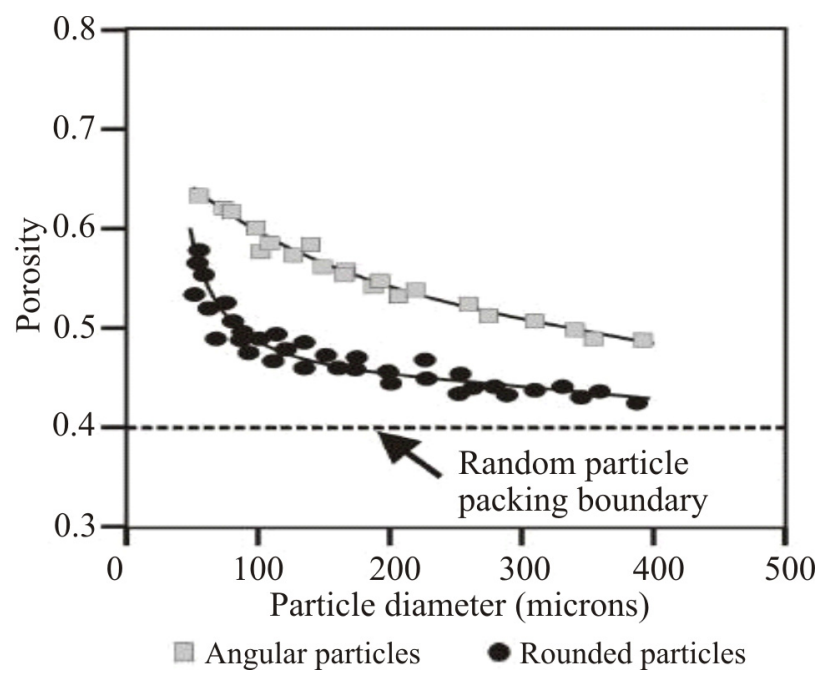

Fig. 6. The dependence of porosity on particle size [42]
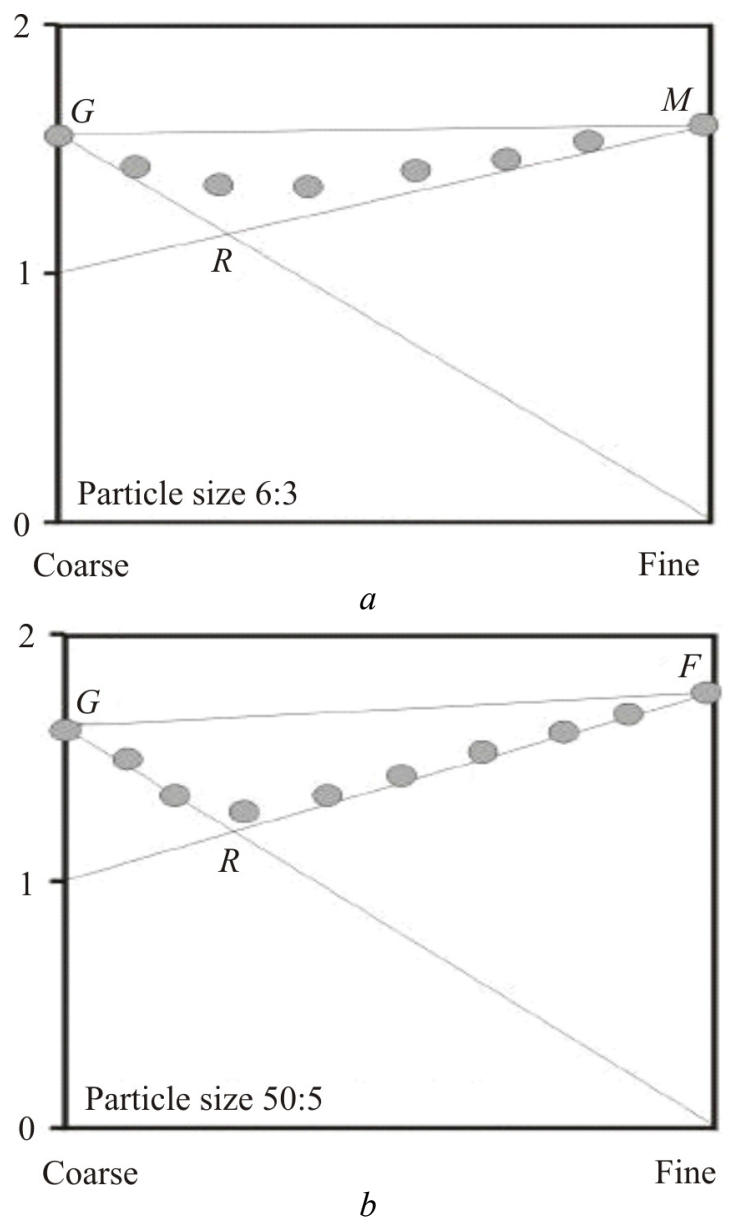

Fig. 7. Simulated influence of a mixture of particles of different sizes (particle size fractions) on the porosity of rocks [42]

Of course, real rocks are usually composed of a continuous range of particle sizes, and this leads to a rather complex scenario, where fractal concepts become useful. There are several known examples of the application of fractal theory to the estimation of reservoir properties of oil-bearing rocks [29]; one of such examples is the dependence between fractality and oil saturation. We also tried to calculate average diameters of particles and fractality indices for the abovementioned groups of rocks according to the following formula:

$$
\frac{1}{d_{\mathrm{cp}}}=\frac{1}{2}\left(\frac{1}{d_{n_{1}}}+\frac{1}{d_{n_{2}}}\right)
$$

where $d_{\mathrm{cp}}$ is the average particle diameter; $d_{n_{1}}$ is the diameter of $n_{1}$ particles; $d_{n_{2}}$ is the diameter of $n_{2}$ particles.

The results of the calculations made (Figure 8) illustrate the influence of the fractality index on the oil saturation with the determined correlation dependence. A rather high correlation coefficient $(0,8)$ of the obtained exponential dependence indicates that the relation between the oil saturation and fractality index is well manifested and credible.

\section{Conclusion}

The study of the methods for simulating the multimodal distribution of interparticle porosity and analytical generalization of the particle size distribution analysis data on cores from one of a well-known and long operated oil and gas fields in Azerbaijan revealed the patterns of pore volume densification in productive reservoirs depending on the depth. The correlation between the specific surface area and oil saturation was also determined. The obtained results are based on statistical estimations of the degree of the influence of particular fractions (including prevailing fractions) on the porosity of different types of reservoir rocks.

In particular, in argillaceous-silty sand, increased content of the prevailing fraction $(0.175 \mathrm{~mm})$ leads to higher porosity, whereas an increased content of the fraction having a particle size of $0.055 \mathrm{~mm}$ reduces the porosity of this group of rocks. In the remaining studied groups of rocks (argillo-arenaceous siltstone, sandy-argillaceous siltstone, and argillaceous sandy loam) the fraction having particle size of $0.055 \mathrm{~mm}$ turned out to be prevailing, and the fractions having a particle size of 0.175 and $0.01 \mathrm{~mm}$ were present in various quantities. The same way as in the first group of rocks, the coarse-grained fraction $(0.25 \mathrm{~mm})$ in this group represented an insignificant amount and was neglected. 


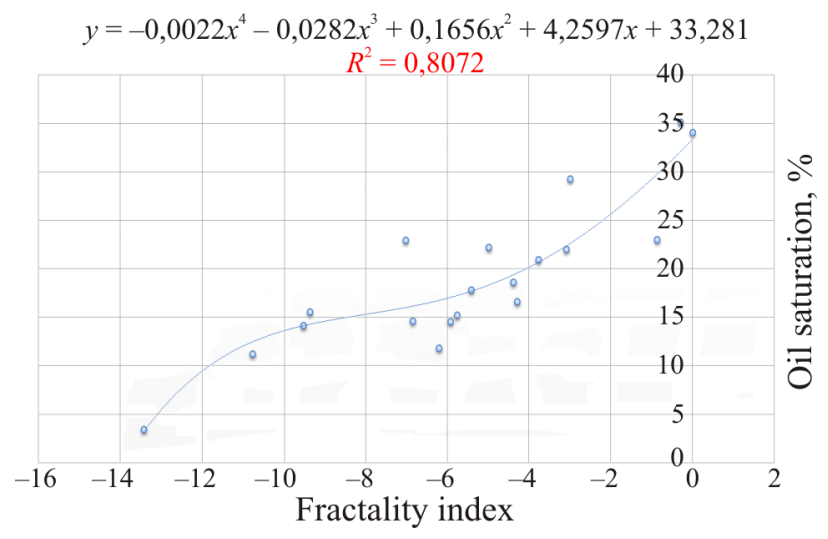

Fig. 8. Dependence of the oil saturation of reservoirs on the fractality index

The data obtained demonstrate that an increased content of the prevailing particle size fraction and fraction having a particle size of $0.175 \mathrm{~mm}$ in argilloarenaceous siltstone leads to higher porosity, whereas in the group of sandy-argillaceous siltstone the influence of the prevailing particle size fraction $(0.055 \mathrm{~mm})$ and a coarser fraction $(0.25 \mathrm{~mm})$ on porosity is negative.

In argillaceous sandy loam, the influence of the prevailing particle size fraction $(0.055 \mathrm{~mm}$, fine $)$ and the secondary particle size fraction $(0.175 \mathrm{~mm}$, coarser) on porosity has the opposite effect in the same way as in the group of argillaceous-silty sand. Thus, an increase in the content of the fine particle size fraction (0.055 $\mathrm{mm}$, prevailing) in argillaceous sandy loam leads to lower porosity, whereas an increase in the coarser particle size fraction $(0.175 \mathrm{~mm})$ content increases the porosity.

Moreover, we made several calculations to trace the relationship between the fractality index and oil saturation; as a result, we obtained an exponential dependence showing the relationship between the oil saturation and fractality index.

\section{References}

1. Anderson E.M. The dynamics of faulting. 2nd ed. Edinburgh, Oliver and Boyd, 1951, 206 p.

2. Aydin A., Borja R.I., Eichhubl P. Geological and mathematical framework for failure modes in granular rock. J. Struct. Geol., 2006, 28, pp.83-98. DOI: $10.1016 /$ j.jsg.2005.07.008

3. Bésuelle P., Rudnicki J.W. Localization: Shear bands and compaction bands, in mechanics of fluid-saturated rocks. International Geophysics. Ed. by Y. Guéguen, M. Boutéca. Amsterdam, Elsevier, 2004, 89, pp.219-321. DOI: 10.1016/S0074-6142(03)80021-9
4. Bjorlykke K. Effects of compaction processes on stresses, faults, and fluid flow in sedimentary basis; examples from the Norwegian Margin. Geological Society Special Publications, 2006, vol.253 (1), pp.359-379. DOI: 10.1144/GSL.SP.2006.253.01.19

5. Bjorlykke K., Jahren J., Mondol N.H. Mechanical and chemical compaction processes in siliceous and carbonate rocks; a comparison. International Geological Congress Abstracts Congres Geologique International Resumes, 2004, vol.1, $163 \mathrm{p}$.

6. Bjorlykke K., Grande L., Kjeldstad A. Properties of faults in subsiding sedimentary basins; examples from the Haltenbanken offshore Norway and the North Sea. AAPG, 2004, available at: http://www.searchanddiscovery.com/documents/abstracts/hedberg2004austin/short/bjorlykke.htm (accessed 12 January 2019).

7. Bjorlykke K., Gundersen Y.G., Jahren J. Compaction driven fluid flow in overpressured compartments. Annual Meeting Expanded Abstracts $A A P G, 2004$, vol.13, 14 p.

8. Bjorlykke K. Clay mineral diagenesis in sedimentary basins; a key to the prediction of rock properties, examples from the North Sea Basin. Clay Minerals, 1998, vol.33/1, pp.15-34. DOI: 10.1180/claymin.1998.033.1.03

9. Levchuk M.A., Bukreeva G.F. O sortirovannosti terrigennykh osadkov i velichinakh, usredniaiushchikh granulometricheskii sostav [On the sorting of terrigenous sediments and the values averaging the particle size distribution]. Geotsiklichnost. Novosibirsk, IGiG, 1976.

10. Romanovskii S.I. Primenenie teorii informatsii dlia resheniia nekotorykh zadach litologii [Application of information theory to solve some problems of lithology]. Matematicheskie metody $v$ geologii. Leningrad, VSEGEI, 1968, pp.75-92.

11. Bump A.P., Davis G.H. Late cretaceousearly tertiary laramide deformation of the northern Colorado Plateau, Utah and Colorado. J. Struct. Geol, 2003, 25, pp.421-440. DOI:10.1016/S0191-8141(02) 00033-0

12. Chan M.A., Netoff D., Blakey R.C., Kocurek G., Alvarez W. Clastic-injection pipes and syndepositional deformation structures in Jurassic eolian deposits: Examples from the Colorado Plateau, in Sand Injectites: Implications for Hydrocarbon Exploration and Production. Ed. by A. Hurst, J.A. Cartwright. AAPG Mem., 2007, 87, pp.233-244. DOI: 10.1306/1209867M871350 
13. Chuhan F.A., Kjeldstad A., Bjorlykke K., Hoeg K. Experimental compression of loose sands; relevance to porosity reduction during burial in sedimentary basins. Canadian Geotechnical Journal $=$ Revue Canadienne de Geotechnique, 2003, vol.40/5, pp.995-1011. DOI: http://dx.doi.org/10.1139/T03-050

14. Chuhan F.A., Kjeldstad A., Bjorlykke K., Hoeg K. Porosity loss in sand by grain crushing; experimental evidence and relevance to reservoir quality. Marine and Petroleum Geology, 2002, vol.19/1, pp.39-53. DOI: 10.1016/S0264-8172(01)00049-6

15. Croize D., Bjorlykke K., Dysthe D.K., Renard F., Jahren J. Deformation of carbonates, experimental mechanical and chemical compaction. Geophysical Research Abstracts, 2008, vol.10.

16. Cuss R.J., Rutter E.H., Holloway R.F. The application of critical state soil mechanics to the mechanical behavior of porous sandstones. Int. J. Rock Mech. Min. Sci., 2003, 40, pp.847-862. DOI: 10.1016/S1365- 1609(03)00053-4

17. Davis R.O., Selvadurai A.P.S. Plasticity and geomechanics. Cambridge: Cambridge Univer. Press, 2002, 287 p. DOI: $10.1017 /$ CBO9780511614958

18. Doelling H.H., Willis G.C. Geologic map of the Smoky Mountain $30^{\prime} \times 60^{\prime}$ quadrangle, Kane and San Juan Counties, Utah, and Coconino County, Arizona, Utah Geol. Surv., Salt Lake City, 2006.

19. Fossen H., Schultz R.A., Shipton Z.K., Mair K. Deformation bands in sandstone: A review. J. Geol. Soc., 2007, 164, pp.755-769. DOI: $10.1144 / 0016-76492006-036$

20. Grueschow E., Rudnicki J.W. Elliptic yield cap constitutive modeling for high porosity sandstone. Int. J. Solids Struct, 2005, 42, pp.4574-4587. DOI: 10.1016/j.jjsolstr.2005.02.001

21. Glover P. Formation evaluation MSc Course notes (Porosity), 2016, pp.43-46.

22. Haimson B., Lee H. Borehole breakouts and compaction bands in two high porosity sandstones. Int. J. Rock Mech. Min. Sci., 2004, 41, pp.287-301. DOI: 10.1016/j.ijrmms.2003.09.001

23. Holcomb D., Rudnicki J.W., Issen K.A., Sternlof K. Compaction localization in the Earth and the laboratory: State of the research and research directions. Acta Geotech., 2007, 2, pp.1-15. DOI: $10.1007 / \mathrm{s} 11440-007-0027-\mathrm{y}$

24. Issen K.A., Challa V. Influence of the intermediate principal stress on the strain localization mode in porous sandstone. J. Geophys. Res., 2008, 113, B02103. DOI: 10.1029/2005JB004008
25. Issen K.A., Rudnicki J.W. Conditions for compaction bands in porous rock. J. Geophys. Res, 2000, 105. DOI: 10.1029/ 2000JB900185

26. Jaeger J.C., Cook N.G.W., Zimmermann R.W. Fundamentals of rock mechanics. 4th ed. Blackwell, Oxford, 2007, $475 \mathrm{p}$.

27. Bjørlykke K. Petroleum geoscience: from sedimentary environments to rock physics. SpringerVerlag Berlin Heidelberg; Department of Geosciences University of Oslo, 2010, 508 p.

28. Bjorlykke K., Jahren J. et al. Sediment compaction and rock properties. AAPG International Conference and Exhibition. Cape Town, 2008.

29. Zapivalov N.P., Smirnov G.I., Kharitonov V.I. Fraktaly i nanostruktury $\mathrm{v}$ neftegazovoi geologii i geofizike [Fractals and nanostructures in oil and gas geology and geophysics]. Novosibirsk, Geo, 2009, $130 \mathrm{p}$.

30. Marcussen Ø., Thyberg B.I., Peltonen C., Jahren J., Bjørlykke K., Faleide J.I. Physical properties of Cenozoic mudstones from the northern North Sea: Impact of clay mineralogy on compaction trends. AAPG Bulletin, 2009, vol.93, pp.127-150. DOI: $10.1306 / 08220808044$

31. Lade P.V. Overview of constitutive models for soils. Ed. by J.A. Yamamuro, V.N. Kalaikin. Soil Constitutive Models: Evaluation, Selection, and Calibration: ASCE Geotech. Spec. Publ., 2005, pp.1-34, 128. DOI: 10.1061/40786(165)1

32. McGarr A. On the state of lithospheric stress in the absence of applied tectonic forces. J. Geophys. Res., 1988, 93, pp.13, 609-613, 617. DOI: 10.1029/JB093iB11p13609

33. Mollema P.N., Antonellini M.A. Compaction bands: A structural analog for anti-mode I cracks in aeolian sandstone. Tectonophysics, 1996, 267, 209-228. DOI: 10.1016/S0040-1951(96)00098-4.

34. Muir Wood D. Soil behaviour and critical state soil mechanics. Cambridge, Cambridge Univ. Press, 1990, $462 \mathrm{p}$.

35. Mondol N.H., Bjørlykke K., Jahren J., Høeg K. Experimental mechanical compaction of clay mineral aggregates - changes in physical properties of mudstones during burial. Marine and Petroleum Geology, 2007, vol.24, pp.289-311. DOI: $10.1016 /$ j.marpetgeo.2007.03.006

36. Gasanov A.B., Mamedova D.N., Abbasov E.Iu. Geologo-geofizicheskaia izuchennost razreza PT IuzhnoKaspiiskoi vpadiny (nekotorye voprosy prognoznoi otsenki osadochnogo kompleksa) [Geological and geophysical exploration of the transverse section of the 
South Caspian basin (some issues of the forecast assessment of the sedimentary complex)]. Moscow, Lambert Academic Publishing, 2017, $109 \mathrm{p}$.

37. Olsson W.A. Theoretical and experimenttal investigation of compacttion bands in porous rock. J. Geophys. Res., 1999, 104, pp.7219-7228. DOI: 10.1029/1998JB900120

38. Olsson W.A. Origin of Lüders' bands in deformed rock. J. Geophys. Res., 2000, 105, pp.5931-5938. DOI: 10.1029/1999JB900428

39. Paterson M.S., Wong T.-F. Experimental rock deformation - the brittle field. 2nd ed. Berlin: Springer, 2005, $347 \mathrm{p}$.

40. Peltonen C., Marcussen O., Bjorlykke K., Jahren J. Mineralogical control on mudstone compaction; a study of Late Cretaceous to early Tertiary mudstones of the Voring and More Basins, Norwegian Sea. Petroleum Geoscience, 2008, vol.14/2, pp.127-138. DOI: 10.1144/1354-079308-758

41. Schultz R.A., Okubo C.H., Fossen H. Porosity and grain size controls on compaction band formation in Jurassic Navajo Sandstone. Geophysical Research Letters, 2010, vol.37, L22306. DOI: 10.1029/2010GL044909

42. Rudnicki J.W. Shear and compaction band formation on an elliptic yield cap. J. Geophys. Res., 2004, 109, B03402. DOI: 10.1029/2003JB002633

43. Sargent K.A., Hansen S.E. Bedrock geologic map of the Kaiparowits coal-basin area, Utah, U.S. Geol. Surv. Misc. Invest. Map, I-1033-I. 1982. DOI: 10.3133/i1033I

44. Thyberg B.I., Jordt H., Bjørlykke K., Faleide J.I. Relationships between sequence stratigraphy, mineralogy and geochemistry in Cenozoic sediments of the northern North Sea. Geological Society, London, Special Publications, 2000, vol.167, pp.245-272. DOI: 10.1144/GSL.SP.2000.167.01.10

\section{Библиографический список}

1. Anderson E.M. The dynamics of faulting. 2nd ed. - Edinburgh: Oliver and Boyd, 1951. - 206 p.

2. Aydin A., Borja R.I., Eichhubl P. Geological and mathematical framework for failure modes in granular rock // J. Struct. Geol. - 2006. - 28. P. 83-98. DOI: 10.1016/j.jsg.2005.07.008

3. Bésuelle P., Rudnicki J.W. Localization: Shear bands and compaction bands, in mechanics of fluid-saturated rocks // International Geophysics / ed. By Y. Guéguen, M. Boutéca. -
Amsterdam: Elsevier, 2004. - 89. - P. 219-321. DOI: $10.1016 / \mathrm{S} 0074-6142(03) 80021-9$

4. Bjorlykke K. Effects of compaction processes on stresses, faults, and fluid flow in sedimentary basis; examples from the Norwegian Margin // Geological Society Special Publications. 2006. - Vol. 253 (1). - P. 359-379. DOI: 10.1144/GSL.SP.2006.253.01.19

5. Bjorlykke K., Jahren J., Mondol N.H. Mechanical and chemical compaction processes in siliceous and carbonate rocks; a comparison // International Geological Congress Abstracts - Congres Geologique International Resumes. - 2004. - Vol. 1. - 163 p.

6. Bjorlykke K., Grande L., Kjeldstad A. Properties of faults in subsiding sedimentary basins; examples from the Haltenbanken offshore Norway and the North Sea [Электронный ресурс]. - AAPG, 2004. - URL: http://www.searchanddiscovery.com/documents/abstracts/hedberg2004austin/ short/bjorlykke.htm (дата обращения: 12.01.2019).

7. Bjorlykke K., Gundersen Y.G., Jahren J. Compaction driven fluid flow in overpressured compartments // Annual Meeting Expanded Abstracts AAPG. - 2004. - Vol. 13. - 14 p.

8. Bjorlykke K. Clay mineral diagenesis in sedimentary basins; a key to the prediction of rock properties, examples from the North Sea Basin // Clay Minerals. - 1998. - Vol. 33/1. - P. 15-34. DOI: $10.1180 /$ claymin.1998.033.1.03

9. Левчук М.А., Букреева Г.Ф. О сортированности терригенных осадков и величинах, усредняющих гранулометрический состав // Геоцикличность. - Новосибирск: ИГиГ, 1976.

10. Романовский С.И. Применение теории информации для решения некоторых задач литологии // Математические методы в геологии. Л.: ВСЕГЕИ, 1968. - С. 75-92.

11. Bump A.P., Davis G.H. Late cretaceousearly tertiary laramide deformation of the northern Colorado Plateau, Utah and Colorado // J. Struct. Geol. - 2003. - 25. - P. 421-440. DOI: $10.1016 / \mathrm{S} 0191-8141(02)$ 00033-0

12. Clastic-injection pipes and syndepositional deformation structures in Jurassic eolian deposits: Examples from the Colorado Plateau, in Sand Injectites: Implications for Hydrocarbon Exploration and Production / M.A. Chan, D. Netoff, R.C. Blakey, G. Kocurek, W. Alvarez; ed. by A. Hurst, J.A. Cartwright // AAPG Mem. - 2007. - 87. P. 233-244. DOI: 10.1306/1209867M871350 
13. Experimental compression of loose sands; relevance to porosity reduction during burial in sedimentary basins / F.A. Chuhan, A. Kjeldstad, K. Bjorlykke, K. Hoeg // Canadian Geotechnical Journal = Revue Canadienne de Geotechnique. - 2003. - Vol. 40/5. - P. 995-1011. DOI: http://dx.doi.org/10.1139/T03-050

14. Porosity loss in sand by grain crushing; experimental evidence and relevance to reservoir quality / F.A. Chuhan, A. Kjeldstad, K. Bjorlykke, K. Hoeg // Marine and Petroleum Geology. - 2002. - Vol. 19/1. - P. 39-53. DOI: $10.1016 / \mathrm{S} 0264-8172(01) 00049-6$

15. Deformation of carbonates, experimental mechanical and chemical compaction / D. Croize, K. Bjorlykke, D.K. Dysthe, F. Renard, J. Jahren // Geophysical Research Abstracts. - 2008. - Vol. 10.

16. Cuss R.J., Rutter E.H., Holloway R.F. The application of critical state soil mechanics to the mechanical behaviour of porous sandstones // Int. J. Rock Mech. Min. Sci. - 2003. - 40. - P. 847-862. DOI: 10.1016/S1365- 1609(03)00053-4

17. Davis R.O., Selvadurai A.P.S. Plasticity and geomechanics. - Cambridge: Cambridge Univer. Press, 2002. - 287 p. DOI: $10.1017 /$ CBO9780511614958

18. Doelling H.H., Willis G.C. Geologic map of the Smoky Mountain $30^{\prime} \times 60^{\prime}$ quadrangle, Kane and San Juan Counties, Utah, and Coconino County, Arizona, Utah Geol. Surv., Salt Lake City, 2006.

19. Deformation bands in sandstone: A review / H. Fossen, R.A. Schultz, Z.K. Shipton, K. Mair // J. Geol. Soc. - 2007. - 164. - P. 755-769. DOI: $10.1144 / 0016-76492006-036$

20. Grueschow E., Rudnicki J.W. Elliptic yield cap constitutive modeling for high porosity sandstone // Int. J. Solids Struct. - 2005. - 42. - P. 4574-4587. DOI: 10.1016/j.ijsolstr.2005.02.001

21. Glover P. Formation evaluation MSc Course notes (Porosity). - 2016. - P. 43-46.

22. Haimson B., Lee H. Borehole breakouts and compaction bands in two high-porosity sandstones // Int. J. Rock Mech. Min. Sci. - 2004. - 41. P. 287-301. DOI: 10.1016/j.ijrmms.2003.09.001

23. Compaction localization in the Earth and the laboratory: State of the research and research directions / D. Holcomb, J.W. Rudnicki, K.A. Issen, K. Sternlof // Acta Geotech. - 2007. - 2. - P. 1-15. DOI: $10.1007 / \mathrm{s} 11440-007-0027-y$

24. Issen K.A., Challa V. Influence of the intermediate principal stress on the strain localization mode in porous sandstone // J. Geophys. Res. - 2008. 113. - B02103. DOI: 10.1029/2005JB004008

25. Issen K.A., Rudnicki J.W. Conditions for compaction bands in porous rock // J. Geophys. Res. 2000. - 105. DOI: 10.1029/2000JB900185

26. Jaeger J.C., Cook N.G.W., Zimmermann R.W. Fundamentals of rock mechanics. -4 th ed. Blackwell, Oxford, 2007. - 475 p.,

27. Bjørlykke K. Petroleum geoscience: from sedimentary environments to rock physics. Springer-Verlag Berlin Heidelberg; Department of Geosciences University of Oslo, 2010. - 508 p

28. Sediment compaction and rock properties / K. Bjorlykke, J. Jahren [et al.] // AAPG International Conference and Exhibition. - Cape Town, 2008.

29. Запивалов Н.П., Смирнов Г.И., Харитонов В.И. Фракталы и наноструктуры в нефтегазовой геологии и геофизике. - Новосибирск: Гео, 2009. - $130 \mathrm{c}$.

30. Physical properties of Cenozoic mudstones from the northern North Sea: Impact of clay mineralogy on compaction trends / Ø. Marcussen, B.I. Thyberg, C. Peltonen, J. Jahren, K. Bjørlykke, J.I. Faleide // AAPG Bulletin. - 2009. - Vol. 93. P. 127-150. DOI: $10.1306 / 08220808044$

31. Lade P.V. Overview of constitutive models for soils / ed. by J.A. Yamamuro, V.N. Kalaikin // Soil Constitutive Models: Evaluation, Selection, and Calibration: ASCE Geotech. Spec. Publ., 2005. P. 1-34, 128. DOI: $10.1061 / 40786(165) 1$

32. McGarr A. On the state of lithospheric stress in the absence of applied tectonic forces // J. Geophys. Res. - 1988. - 93. - P. 13, 609-613, 617. DOI: $10.1029 / J B 093 i B 11 \mathrm{p} 13609$

33. Mollema P.N., Antonellini M.A. Compaction bands: A structural analog for anti-mode I cracks in aeolian sandstone // Tectonophysics. - 1996. - 267. P. 209-228. DOI: 10.1016/S0040-1951(96)00098-4.

34. Muir Wood D. Soil behaviour and critical state soil mechanics. - Cambridge: Cambridge Univ. Press, 1990. $-462 \mathrm{p}$.

35. Experimental mechanical compaction of clay mineral aggregates - changes in physical properties of mudstones during burial / N.H. Mondol, K. Bjørlykke, J. Jahren, K. Høeg // Marine and Petroleum Geology. - 2007. - Vol. 24. - P. 289-311. DOI: 10.1016/j.marpetgeo.2007.03.006

36. Гасанов А.Б., Мамедова Д.Н., Аббасов Э.Ю. Геолого-геофизическая изученность разреза ПТ Южно-Каспийской впадины (некоторые вопросы прогнозной оценки осадочного 
комплекса). - M.: Lambert Academic Publishing, 2017. - $109 \mathrm{c}$.

37. Olsson W.A. Theoretical and experimental investigation of compaction bands in porous rock // J. Geophys. Res. - 1999. - 104. - P. 7219-7228. DOI: $10.1029 / 1998 J B 900120$

38. Olsson W.A. Origin of Lüders' bands in deformed rock // J. Geophys. Res. - 2000. - 105. P. 5931-5938. DOI: 10.1029/1999JB900428

39. Paterson M.S., Wong T.-F. Experimental rock deformation - the brittle field. - 2nd ed. Berlin: Springer, 2005. $-347 \mathrm{p}$.

40. Mineralogical control on mudstone compaction; a study of Late Cretaceous to early Tertiary mudstones of the Voring and More Basins, Norwegian Sea / C. Peltonen, O. Marcussen, K. Bjorlykke, J. Jahren // Petroleum Geoscience. - 2008. - Vol. 14/2. - P. 127-138. DOI: $10.1144 / 1354-079308-758$
41. Schultz R.A., Okubo C.H., Fossen H. Porosity and grain size controls on compaction band formation in Jurassic Navajo Sandstone // Geophysical Research Letters. - 2010. - Vol. 37. L22306. DOI: 10.1029/2010GL044909

42. Rudnicki J.W. Shear and compaction band formation on an elliptic yield cap // J. Geophys. Res. 2004. - 109. - B03402. DOI: 10.1029/2003JB002633

43. Sargent K.A., Hansen S.E. Bedrock geologic map of the Kaiparowits coal-basin area, Utah, U.S. Geol. Surv. Misc. Invest. Map, I-1033-I. - 1982. DOI: $10.3133 / 11033$ I

44. Relationships between sequence stratigraphy, mineralogy and geochemistry in Cenozoic sediments of the northern North Sea / B.I. Thyberg, H. Jordt, K. Bjørlykke, J.I. Faleide // Geological Society, London, Special Publications. - 2000. - Vol. 167. - P. 245-272. DOI: 10.1144/GSL.SP.2000.167.01.10

Please cite this article in English as:

Hasanov A.B., Abbasova G.G. Analysis of the fractal structure and stochastic distribution of pores in oil and gas reservoirs. Perm Journal of Petroleum and Mining Engineering, 2019, vol.19, no.3, pp.228-239. DOI: 10.15593/2224-9923/2019.3.3

Просьба ссылаться на эту статью в русскоязычных источниках следующим образом:

Гасанов А.Б., Аббасова Г.Г. Оценка фрактальной структуры и стохастического распределения поровых пустот нефтеносных коллекторов // Вестник Пермского национального исследовательского политехнического университета. Геология. Нефтегазовое и горное дело. - 2019. - Т.19, №3. - С.228-239. DOI: 10.15593/2224-9923/2019.3.3 